\title{
The Communist International, the Soviet Union, and their impact on the Latin America Workers' Movement
}

DAN LA BOTZ

\begin{abstract}
The Soviet Union and the Communist International had an adverse influence on the Latin American workers' movement, continually diverting it fighting for a democratic socialist society. They subordinated the workers' movements to the interests of the Soviet Union's ruling class, the Communist bureaucracy. At one moment, they led the workers' movement in disastrous uprisings, while in a subsequent era they encouraged it to build alliances with capitalist and imperialist power.
\end{abstract}

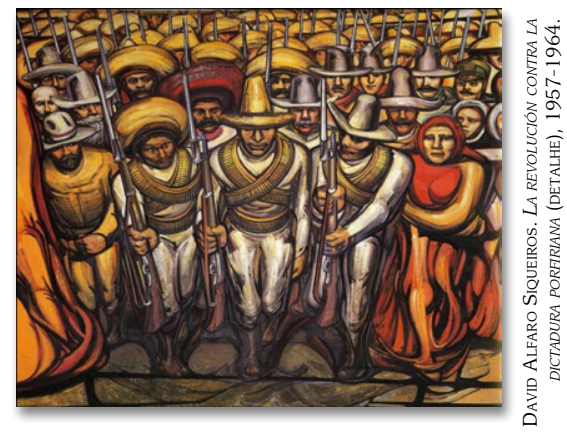

Keywords: Soviet Union. Communist International. Communist Parties. Cuba. Workers Movement.

\section{A Internacional Comunista, a União Soviética e seu impacto no movimento de trabalhadores da América Latina}

\section{Dan La Botz}

Ph.D in American history and professor at the Murphy Institute, the labor school of the City University of New York. He is the author of ten books on labor, social movements, and politics in the United States, Mexico, Nicaragua, and Indonesia. E-mail: danlabotz@gmail.com.
Resumo: A União Soviética e a Internacional Comunista tiveram uma influência adversa no movimento latino-americano de trabalhadores, frequentemente, distraindo-o de sua luta por uma sociedade socialista democrática. Ambas subordinaram os movimentos de trabalhadores aos interesses da classe dominante na União Soviética, a burocracia comunista. Em um momento, dirigiram o movimento de trabalhadores para levantes desastrosos, enquanto em um período subsequente encorajaram-no a fazer alianças com poderes capitalistas e imperialistas.

Palavras-chaves: União Soviética. Internacional Comunista. Partidos Comunistas. Cuba. Movimento de Trabalhadores.

RECEBIDO 28.03.2017

APROVADO 20.05.2017 


\section{INTRODUCTION}

The Soviet Union and the Communist International worked to influence Latin America from 1918 until the dissolution of the Soviet Union and the Eastern Bloc in 1991. How do we evaluate the impact of the Soviet Union and the Communist International on the workers' movement in Latin America? One can judge the Communist parties by the size of their organizations, or by their influence in the labor unions, or by the numbers of people they elected to parliaments, or the number who received ministerial portfolios in government. One can look too at the impact of Communist ideas on the society more broadly and perhaps even of what can be called Communist culture. ${ }^{1}$ Certainly all of those are significant gauges. The better measure of the Communists would be, however, what they generally claimed was their own criterion: that is, their success or failure in furthering the goal of building a movement from below to bring working people to power and to create socialist society. This is the criterion used in this article to look at the role of the Communist International and the Soviet Union in Latin America from 1918 until the collapse of the Soviet Union and the Eastern Bloc in 1991.

The contention here is that the Communist International and Soviet Union had, throughout nearly their entire history, an adverse influence on the workers' movement, continually diverting it from the goal of fighting for a democratic socialist society. The rulers of the Soviet Union directed the Communist parties around the world, including in Latin America, through the Communist International (Comintern) (1919-1943) - later the Communist Information Bureau (Cominform) (1947-1956) - and after that through the Communist Party of the Soviet Union and the Soviet embassies. They subordinated the workers' movements to the interests of the Soviet Union; or, to be exact, to the interests of the Soviet ruling class, the Communist bureaucracy. ${ }^{2}$

1 Communism with a capital C refers to the Communist model whose principle examples in the twentieth century were the Soviet Union, China and Cuba.

2 The Soviet Union, China, Vietnam, North Korea, and Cuba were, in the twentieth century, societies that would be best described as bureaucratic collectivist, ruled by a Communist bureaucracy that owned the state and through it the means of production. 
In making such an evaluation, it is not simply a question of drawing up a balance sheet of assets and liabilities, but of understanding the overall impact of Communism on the workers' movements. The Communist International and the Soviet Union at one moment led the Latin American workers' movement to engage in ill-conceived and disastrous uprisings, while in a subsequent era they encouraged the workers' movement to build alliances with capitalist and imperialist powers. By the late 1920s, the Soviet Communist model of the authoritarian party, the one-party state, and the quasi-religious Marxist-Leninist ideology had replaced the Marxist socialist notion of a democratically organized labor movement and socialist parties fighting for the historic the goal of establishing a democratic socialist state. Those two issues-subordination to Soviet interests and the distortion of socialist valuesmeant that the Latin American Communist parties had a negative and destructive impact on the workers movement.

\section{THE HISTORIOGRAPHY}

Throughout the Cold War era, historiography on Latin American Communism was dominated by the notion of a struggle between Soviet totalitarianism and Western Democracy (JACOBSON, 1994). Western, mostly U.S. historians argued that the Soviet Union and the Communist International wished to lead a worldwide revolution that would destroy democracy and impose everywhere a totalitarian political and social system such as existed in the Soviet Union. As expressed by Hannah Arendt, whose book The Origins of Totalitarianism (1951) became a touchstone text for Cold War thinking, Nazi Germany and the Soviet Union both created societies which were the polar opposite of bourgeois democracy with its "lawful government" and "positive laws" (ARENDT, 1976). ${ }^{3}$ She asserted the superiority of bourgeois democracy over totalitarianism. In bourgeois democratic societies one has freedom of the press, of assembly, and of petition, all of which make it possible

3 See especially her final chapter, "Ideology and Terror: A Novel form of Government" (ARENDT, 1976, p. 460 - 479). 
not only to organize and protest, but also to change the government, if not the nature of the regime. Taken alone, however, her book Totalitarianism presented a distorted view of reality because she offered no similar critique of capitalism and its quite limited democracy or of the lack of democracy in its neo-colonial empires.

Yet, totalitarianism, defined differently, might have provided a useful framework. It is often forgotten that the term "totalitarian" as applied to the Communist Party and the Soviet Union was first used by the Left, by anarchists, socialists, and Trotskyists. Leon Trotsky wrote in The Revolution Betrayed in 1936 that, "The [Communist Soviet] regime had become 'totalitarian' in character several years before this word arrived from Germany." ${ }^{4}$ Or, as he writes more precisely, "[...] the Soviet state has acquired a totalitarian-bureaucratic character". (TROTSKY, 1967, p. 100). As used by Trotsky and other leftists, the term "totalitarian" as applied to the Soviet Union and the Communist parties was used not in comparison to bourgeois democracy but in contrast to the notion of socialist democracy. Of course, this is not only quite different but also the antithesis of the Cold War usage of totalitarianism, which was used not only to attack Soviet Communism, but also to attempt to discredit Marxism and the entire socialist project.

An understanding of the totalitarian character of Soviet Communism in Trotsky's sense is essential in attempting to comprehend the role of the Soviet Union and the Communist International in Latin America, though not because the Soviets ever had the capacity to export and to impose such totalitarianism there. In this article then, the totalitarian character of Soviet Communism means the absolute and undemocratic subordination of the labor movement to the interests of the ruling Soviet bureaucracy, which led to the grotesque distortion of socialist ideals. In addition, whatever their immediate objectives or capacity at the moment, Latin American Communist parties always had as their principal goal the creation of a one-party state with a bureaucratic command economy such as existed in the Soviet Union. ${ }^{5}$ The

4 Trotsky (1967, p. 100).

5 Soviet Communism's real goals could be seen in its conquest of Eastern 
Soviet Union, for strategic and logistical reasons, could not always pursue that objective, but whatever the vicissitudes and line of the Soviet Union at any particular moment, subordination to Soviet Communism threw the working class far off course, as democracy as both the means and the goal of socialism disappeared. The embrace of and influence of Soviet Communism on Cuba only confirmed the long-term objective, that is, the establishment of totalitarian states.

\section{MAJOR SCHOOLS OF INTERPRETATION}

The Communist International $(\mathrm{CI})$ and the influence of the Soviet Union in Latin America has been the subject of an extensive critical literature generally dominated by the Cold War perspective. Some Communist writers defended the Communists' global role. William Z. Foster, a major figure in the Communist Party USA for decades - a prominent U.S. labor leader, delegate to the Communist International in the 1920s, Communist Party candidate for U.S. president, and the party's leader from 1945 to 1957 (BARRETT, 1999) - was a loyal supporter of Joseph Stalin, the head of the Soviet Union. Foster wrote both a History of the Three Internationals (1955) and an Outline Political History of the Americas (1951), which included a chapter on "The Russian Revolution and the Communist Movement" in which he discussed the $\mathrm{CI}$ in Latin America. (FOSTER, 1951; 1955). Foster's books retrospectively staunchly defended - from a Stalinist ${ }^{6}$ point of view-every major zig-zag of the Soviet political line. Regarding the CI in Latin America, Foster argued that:

Europe and the imposition of Communist governments there after 1945. One could also see that tendency in Spain during the Civil War (1936-1939) as the Communists and the Soviet Union tended gradually to take over the Republican government while also attempting to exterminate the socialists of the Partido Obrero de Unificación Marxista (POUM) and the anarchists. On this question see Peirats (1971).

6 The term Stalinist here is not an epithet. Foster would certainly have called himself a Stalinist throughout the period from 1927 to 1956 (and perhaps afterwards too). 
The Communist parties of the western hemisphere, like those of the Old World, were not created, as such, by the Russian Revolution. Rather they grew out of actual conditions in their respective nations and were matured by the experiences of the great Russian Revolution in establishing socialism. (FOSTER, 1951, p. 376).

While it is true as he states that in several Latin American countries the new Communist Parties emerged from the older Socialist parties and anarchist labor movements, Foster avoids the issue of the Cl's well-known role in determining the leadership, policies, and practices of those parties, which were in no way autonomous. Foster's official histories provide some useful information but show no desire or willingness to engage critically issues in the $\mathrm{CI}^{\prime} \mathrm{S}$ history.

The U.S. government, dominant world capitalist power and Cold War opponent of the Soviet Union, studied the Soviet Union and the $\mathrm{CI}$ in Latin America extensively and worked to subvert their influence. State Department and CIA archives are filled with reports on the Communists. We see the results of such research in the work of Rollie Poppino, a U.S. intelligence research specialist from 1954-1961 and later a professor of Latin American History at the University of California at Davis (ROLLIE..., 2011), who produced a quite useful study, International Communism in Latin America: A History of the Movement 1917-1963, a book surprisingly devoid of any explicit anti-Communist argument (POPPINO, 1964). He argued, as many others would, that the "Latin American Communist Parties have never been free agents," (POPPINO, 1964, p. 151) controlled as they always were by the CI and the Soviet Union.

Some of the most influential writers on the Communist International, such as Robert J. Alexander and Manuel Caballero, were social democrats who, writing during the Cold War era, criticized the $\mathrm{CI}$ and the Soviet Union for their opposition to democratic institutions such as parliamentary democracy (ALEXANDER, 1957; CABALLERO, 1986). Alexander, a professor at Rutgers University whose book Communism in Latin America was the standard 
history for decades, became a kind of "State Department socialist" (BIOGRAPHICAL..., [s.d.]). A former Socialist Party member who later joined the Social Democrats USA and then Americans for Democratic Action as well as the Council on Foreign Relations, he collaborated with the former Communist Jay Lovestone, director of the International Affairs Department of the AFL-CIO and with the U.S. State Department. Alexander was also part of President John F. Kennedy's task force that, following the Cuban Revolution, recommended the creation of the Alliance for Progress, a development program intended to serve as a counter to the influence of Cuba (RABE, 1999).

An explicit anti-Communist, Alexander believed that the Soviet Union controlled and set the agenda of the Latin American Communist parties and believed they were a threat both Latin American nations and U.S. interests. But he thought that the problem was not to be solved militarily but rather politically. A critic of Latin American dictatorships, he called upon "[...] the United States and other non-Communist countries to demonstrate to the Latin American peoples that they can offer Latin America more effective aid in achieving its goals of higher living standards, more equitable distribution of income, and political democracy than can the Communists" (ALEXANDER, 1957, p. 17). He argued that "recognition of the true nature of the Latin American Communist Parties is all the more necessary, because the salvation of the region from the Communists lies precisely in the real indigenous social reforms, agrarian reforms, and radical nationalists or anti-imperialists" (ALEXANDER, 1957, p. 30).

Another social democratic critic, Manuel Caballero (1931-2010), who went from the Central University of Venezuela (UCV) to the University of London to earn his Ph.D., authored some 50 books on his country's history and politics. He began his political activism as a teenage opponent of the dictator Marcos Pérez Jiménez, joining the Venezuelan Communist Party (PCV), though later he left to join the Movimiento al Socialismo (MAS), a group which criticized the models of the Soviet Union and the Communist Party, eventually breaking with Marxism and becoming a social democratic party. Caballero, a writer for former Communist and ex-guerillero 
Teodoro Petkoff's newspaper Tal Cual, a voice of MAS, won the National Prize for Journalism in 1979 and the National History Prize in 1994. Caballero later became a fierce critic of President Hugo Chávez and the Bolivarian Revolution. His book Latin America and the Comintern, 1919-1943 (1986) dismissed the Communist International for its extreme centralization, verticality, and lack of democracy, as well as for its lack of interest in Latin America, for its view that Latin America's revolution would only come after revolutions in Europe and the United States, and for its failure to succeed anywhere in Latin America in its revolutionary goals (CABALLERO, 1986, p. 149 - 155).

A former revolutionary socialist who became a social democrat was no less critical of the Communist International's record in Latin America, even going so far as to dismiss it (ALBA, 1968, p. 118). ${ }^{7}$ Víctor Alba (1916-2003), born Pere Pagès i Elies in Barcelona, Cataluña, in the Spanish state, became involved as a teenager during the Spanish Civil War period in the Bloque Obero Campesino (BOC) and then in the Partido Obrero de Unificación Marxista (POUM), an alliance of left and right Communists who had left or been expelled from the Communist Party. He was later a writer for the party's publications Última Hora and La Batalla. The POUM, fighting General Francisco Franco's fascists and suffering violent attacks from the Stalinist Communist Party, ${ }^{8}$ formed Alba's early revolutionary socialist politics of opposition to both capitalism and bureaucratic Communism.

Arrested and imprisoned for six years by Franco's dictatorship and then freed in 1943, Alba entered France where he worked with Albert Camus on his journal Combat. Four years later he moved to Mexico, where he produced hundreds of articles and a number of books in Catalan, Spanish, and English. In 1957 he moved to the United States, becoming a professor at the University of Kansas and then at Kent State University in Ohio (MULLAN, 2003). By the

7 Alba wrote, "A history of the labor movement in Latin America could perhaps be written with no more than passing reference to Communism" (ALBA, 1968, p. 118). As his book suggested, this was clearly going too far.

8 Most famously the murder by torture of POUM leader Andrés Nin Pérez. 
1960s he had given up his revolutionary socialist views to become a social democrat writing for publications such as Dissent. He dedicated one scathing chapter of his 1968 book Politics and the Labor Movement in Latin America to the "The Communist Movement" in which he excoriated the Communists for their anti-democratic, often conservative, sometimes disastrous, and always self-serving policies in every period. ${ }^{9}$ Other such social democratic interpretations also existed. ${ }^{10}$

Writing a decade later, Michael Löwy offered a critique from a different point of view. His "Puntos de referencia para una historia del Marxismo en América Latino," written in 1979, is the introduction to his useful collection of Communist and other leftist documents titled El marxismo en América Latina (de 1909 a nuestros días): Antología (LÖWY, 1982). Löwy, born to Austrian immigrants in Brazil in 1938, studied at the University of São Paulo and earned his Ph.D. at the Sorbonne; he later taught at a number of universities in various parts of the world. In France he worked with the League Communiste Revolutionnãire, a section of the Trotskyist Fourth International, during a period when it embraced Fidel Castro and the Cuban Revolution and then Ernesto "Che" Guevara's call for guerrilla groups (focos) to carry out armed struggle in Latin America. Löwy's critique of Communism in Latin America, informed by Trotskyist politics, is critical of the Communist International under Stalin and his successors. Löwy argued that the left should pursue "permanent revolution," the carrying out in a continuous fashion of the bourgeois democratic and socialist revolution. His principal objection was to the Communist policy of the Popular Front and to its "stageism": that is, the idea that a bourgeois revolution must succeed and be consolidated before there could be a

9 Víctor Alba, Politics, (1968, p. 118 - 162).

10 We might also mention Sheldon B. Liss, an American academic of social democratic views, put together a compendium called Marxist Thought in Latin America published in 1984. Liss (1984), who prided himself on his "non-sectarian perspective," produced a book discussing Latin American left intellectuals from nine countries which, while useful as a reference work, was because of its eclectic, evenhanded, and ecumenical approach of little value for those attempting critically understand Latin American Communism and other left currents. 
socialist revolution. Löwy embraced the Cuban Revolution because he saw it as a form of what Trotsky called "permanent revolution," which Löwy thought had also happened in Yugoslavia, China, and Vietnam (LÖWY, 1981). ${ }^{11}$ This, despite the fact that these national revolutions were not led by the working class and in no way furthered democracy. He was virtually uncritical of the Cuban Revolution, which he referred to as having created a socialist state, and praised it for having revived Marxist theory and a revolutionary perspective based on the idea of the "uninterrupted revolution" (LÖWY, 1981, p. 11 - 59). At that time, Löwy did not deal with the fact that Cuba had become a one-party state, had entered the Soviet camp by 1962, and that by 1971 Cuba had completely assimilated to the Soviet Union's economic and political structures (FARBER, 2007).

Beginning in the 1980s, a group of revisionist historians argued against the Cold War historians' idea that the Soviet Union controlled and directed the national Communist parties, emphasizing the autonomous role of the national parties (ISSERMAN, 1982). Some contemporary historians have called for a revision of Communist history that would reduce the role of the Communist International. Seeing the CI as less significant, they would emphasize each country's specific social and cultural elements. For example, Daniel Kersfeld, a professor of Latin American Studies at the National Autonomous University of Mexico (UNAM), has written a short paper about the use of the Comintern archives in Russia for writing the history of the Communism with the title: "From Esotericism to Marketing: Approaches to the Comintern Archives" (2011). Kersfeld calls for a revision in the study of Communism, arguing that Cold War or post-Cold War prejudices, such as the use of the word "totalitarianism" to describe the Soviet Union and other Communist nations, are practices that have warped our perception. He argues that, "The opening of the archives of the Communist International meant a new analysis of the history of communist

11 This book was later reissued with the same title (Chicago: Haymarket Books, [2010]), though it excised Löwy's earlier positive case studies of the twentieth century revolutions, leaving the bare bones of his theory. See La Botz (2011). 
parties, especially in relation to their rise and consolidation, their debates and internal conflicts, and their ties, not always harmonious, with Moscow" (KERSFELD, 2011, p. 73). In fact, however, whatever their debates and conflicts were, and they were many, in the end Latin American parties and their members had to follow the line set in Moscow, as confirmed by recent studies in the Comintern archives. ${ }^{12}$

A recent study of the Latin American left edited by the U.S. academic Carlos Aguirre, Militantes, intelectuales y revolucionarios: Ensayos sobre marxismo e izquierda en América Latina, has few essays on the Communist International and the Communist Parties, but those in the collection support the view that the $\mathrm{CI}$ dictated international Communist policy, even if Latin America posed particular theoretical and political challenges, such the large indigenous population (AGUIRRE, 2013). ${ }^{13}$ Nothing in recent studies leads us to change our understanding of Soviet domination of the Comintern or of its periodization. The emphasis on local and cultural factors, an approach common to post-modernism, tends to minimize international geopolitical factors, reduces the role of the International, and produces a mosaic picture of Communism. But when we step back it is an abstract painting in which the fundamental form of Soviet Communism's influence becomes vague.

The interpretation offered here differs from those of Alexander and Alba because it does not see international Communism's principal problem as its opposition to "democracy," which, after all, means for those historians a formally democratic, liberal capitalist state. It also differs from Caballero in that it does not see international Communism's primary fault or weakness as its failure to carry out the revolutions it proposed, which would have led to societies that looked like Eastern European ones in the Cold War

12 Spenser (1999). While she makes no explicit general statement about the Comintern's relationship to the national Communist Parties, it is clear she believes the latter were subordinate to the former, writing for example that after 1928, "The Comintern gave orders to Communist parties to destroy their rivals" (SPENSER, 1999, p. 18). Klehr, Haynes and Firsov (1995) go much further asserting the International's domination of the CPUSA.

13 A collection of 16 essays on a variety of left experiences. 
period. And it differs from Löwy in that it does not see the Cuban Revolution of 1959 as having produced a socialist society or as having contributed to the development of revolutionary working class movements and socialist theory in the region. Finally, unlike post-modern critics, one must understand that the Soviet Union and the Communist International, whatever national tensions arose, directed the Communist enterprise.

The central question facing working class movements in every country is always its ability to create an independent movement, one that is not controlled by either capitalist parties or by the governments or the bureaucratic Communist parties loyal to one or another of the Communist states (having in mind here not only the Soviet Union, but also Cuba and Communist China). While there was a tremendous initial enthusiasm around the world including in Latin America for the Bolshevik or Soviet revolution, already by the mid-1920s the Soviet Union - through the Communist International - was imposing its national agenda on the international workers' movement by fiat. This meant a series of left and right gyrations that disoriented the various Communist parties and made them worthless as vehicles for an internationalist and democratic revolutionary workers' movements.

\section{PERIODIZATION OF THE COMMUNIST INTERNATIONAL AND SOVIET INFLUENCE}

The role of the Communists in world politics and in Latin America has been divided into several periods that are acknowledged by virtually all scholars. First, the period of European Revolution from 1921-1923; second, the period of capitalist stabilization, the strategy of the United Front of Communists, Socialists, and other leftists, and of the Bolshevization of the Comintern parties from 1924-1927; the Third Period from 1928 to 1935 in which the Communists attacked the Socialists as "social fascists" and attempted to turn working class struggles into insurrections; fourth, the first period of the Popular Front from 1935 until 1939 involving Communist unity with anti-fascist parties of all sorts; fifth, the brief period of the Hitler-Stalin Pact from 1939 to Nazi 
Germany's invasion of the Soviet Union in June 1941; and sixth, the return in 1941 to the Popular Front, including the dissolution of the Comintern in 1943, though continuing with that approach even with the outbreak of the Cold War. That is, the Communist parties continued the Popular Front approach, meaning unity with labor and bourgeois parties within the context of "peaceful coexistence" with the capitalist powers. Despite the Cuban Revolution of 1959, the Communists did not change their fundamental commitment to the Popular Front, which remained their strategy until the fall of the Soviet Union in 1991. The Soviet Union's foreign policy and diplomacy, driven by economic and military needs, sometimes created particular national tensions, but the overall periodization remains the same around the world.

As Marxists, the Bolsheviks believed that their theory of revolution was universal because capitalism had become universal, even if its development was uneven. ${ }^{14}$ As Marxists, they believed that the working class would lead the peasantry in revolution. As Leninists, they believed that their disciplined party, which had succeeded in leading the first successful workers' revolution, represented a model for the world socialist movements. They believed that soviet power, the organization of a government of workers and peasants into councils could also be a model for the world. They saw postWorld War I Europe-and Germany in particular - as the center and most advanced arena of the struggle for workers' power and socialism. But as a nation that stretched across Asia and a country where peasants constituted a majority, they believed that the Russian Revolutionary model was appropriate for the colonial world as well.

Any reading of the documents, of biographies of Latin American leftists, of histories of the Communist parties and the Communist International, and of Latin American-Soviet history makes clear that the Soviet Union and the Communist International determined

14 Post-colonial theorists have made the argument that the theories of Marx, Lenin, Trotsky, Luxemburg and others were "eurocentric," though it would be better to say that it is universal. On this question see Chibber (2013) and Anderson (2016). 
and dictated the overall political direction of the national parties. The CI sent its agents to Latin America and Latin American party leaders traveled to Moscow to receive Stalin's blessing, much as Catholic cardinals and bishops went to the Vatican. There they were informed of the line that they were to carry out. Latin American Communists went to Moscow for education and training. The Latin American Communist party leaders met and cooperated with the Soviet secret police (NKVD, later GPU) who were also involved in the Communist International and attached to Soviet embassies.

The Soviet Union and the Communist International controlled the Latin American Communist parties in much the same way that the U.S. State Department - working through the Central Intelligence Agency (CIA) and hand in glove with the American Federation of Labor-Congress of Industrial Organizations (AFL-CIO) (RADOSH, 1969) - directed capitalist political parties and bureaucratic labor unions in its Latin American sphere of influence. On the other hand, when it could not control governments in Latin America, the United States was likely to send in the Marines and overthrow the offending political party, as it did in Haiti, Nicaragua, Guatemala, or the Dominican Republic (WILLIAMS, 1980; KINZER, 2006), much like the Soviet Union did in its sphere of influence in Eastern Europe where it suppressed rebellions and deposed governments with tanks and troops in East Germany, Poland, Hungary or Czechoslovakia (HARMAN, 1974). Until the Cuban Revolution of 1959 the Soviet Union never intervened directly in Latin America, which formed part of the United States' sphere, just as the United States did not intervene directly in the Soviet sphere of Eastern Europe.

\section{THE FOUNDING OF THE COMMUNIST INTERNATIONAL AND LATIN AMERICA COMMUNIST PARTIES}

The Russian Revolution of October 1917, a workers and peasants' revolutionary movement that under the leadership of the Bolshevik Party overthrew the capitalist Russian Provisional government and handed power to the soviets (councils), had an enormous impact on the left throughout the world. The radicals' 
dream of a workers' revolution that would take power and begin to create a socialist society appeared to be taking place before their eyes. Hundreds of thousands of workers in countries around the world suddenly wanted to be Bolsheviks, to create Soviets, and to begin to construct Communism. The Russian Revolution galvanized the socialist workers' movement and even before the creation of the Communist International, many on the left oriented themselves toward the new world center. Russia, the workers' country, became a magnetic point to which the compasses now all pointed, though as Victor Serge wrote, few even in Europe at the time had any idea what a soviet or a Bolshevik was.

Vladimir Lenin, Leon Trotsky, Grigory Zinoviev and other Bolshevik leaders had an internationalist outlook, but their experience and their vision were primarily European. They had come of age politically within European Social Democracy and the Second International, led by the German Social Democratic Party. The crisis that made their revolution possible was the Great War of 1914-1918, which was fundamentally a European conflict. They were anti-imperialists who understood that Great Britain's dominant power was based on its colonies, and they would support the revolutionary movements in those colonies, but they knew little about them and had had virtually no contact with them. If they had an understanding of any region of the world outside of Europe, it was Asia, because while its center was in Europe, Russia was largely an Asian nation, and Great Britain's most important colony was India. Africa and Latin America were practically terra incognita to the Bolsheviks.

The failure of the Socialist International to oppose the outbreak of World War I, as each Socialist Party rallied to support its government, led to that International's collapse. The anti-war socialist left wing held meetings at Zimmerwald in 1915 and at Kienthal in 1916 (both in Switzerland) and formed a network that laid the basis for the creation of a new International. The Bolsheviks, now called the Communist Party, convened the founding conference of the Communist International that took place in Moscow from March 2-6, 1919; some 54 delegates principally from European nations participated -34 of them voting delegates. Also present 
were representatives of labor and socialist movements of Azerbaijan, China, Korea, Georgia, Turkey, and Turkistan, but no Latin Americans participated. The Founding Congress' agenda, quite understandably, dealt entirely with the Russian situation and the post-war conditions in Europe. The new CI, controlled by its executive committee, was seen as the headquarters of a world revolutionary party organized along quasi-military lines.

After the First Congress, however, Lenin sent Bolshevik organizers to various nations. To Mexico the $\mathrm{CI}$ sent Mikhail Borodin, who found a small cluster of revolutionary socialists, among them US anti-war activist Charles Francis Phillips and the Indian nationalist M.N. Roy and his US wife Evelyn Trent Roy. Borodin selected the Roys to attend the Second Congress of the Communist International, though in the end it was M.N. Roy and Phillips who went.

Only with the Second Congress of the CI held in 1920 did imperialism and colonialism become central topics of discussion while a Latin American nation - Mexico - was represented, and Latin America as a region become a topic of limited discussion. M.N. Roy, who arrived as a delegate for Mexico but left as the delegate of India, became a major figure at the Congress and in the International. He debated Lenin over the question of movements for independence in the colonial world, with Lenin presenting a position supporting the national bourgeoisie's leadership of them, while Roy argued that the national bourgeoisie would capitulate to imperialism. In the end, the Congress surprisingly adopted both resolutions (HAITHCOX, 2015).

Phillips played little role. He did, however, have an interesting conversation with Lenin about the Mexican peasantry. Lenin, confessing that he had only fragmentary knowledge about Mexico, asked Phillips about the role of the Mexican Communist Party in the countryside. Phillips explained that much of the rural population was indigenous, a fact about which Lenin had been ignorant. When Lenin asked if they had publications in the Indian languages, Phillips explained that the indigenous people were illiterate. In that case, said Lenin, they must have organizers who spoke the Indian language, because, said Lenin, "those Indians should be 
your number one objective in the countryside" (SHIPMAN, 1993, p. 125; GÓMEZ , 1964, p. 42 - 43). This would also be the view several years later of the Peruvian José Carlos Mariátegui in a document that he wrote for the debate in the Communist International (MARIÁTEGUI, 1991, p. 210 - 257).

Speaking at the Congress on the national and colonial questions, Lenin boldly asserted that the Communists would provide leadership to the colonial peoples and their largely peasant populations. As he stated:

The preponderance of precapitalist relationships is still the main determining feature in these countries so that there can be no question of a purely proletarian movement in them. There is practically no industrial proletariat in these countries. Nevertheless, we have assumed, we must assume, the role of leader even there (RIDDELL, 1991, p. 214).

Lenin went on to add that Communist-led organizations could organize peasant soviets even in the economically "backward countries". While Lenin was thinking principally about China and India, his audacious prescription for Communist leadership of the colonial nations and their largely peasant populations could presumably also be applied to Latin America.

It was the brilliant US radical Louis Fraina, also speaking at the session on the national and colonial question, who first introduced the question of Latin America explicitly, arguing that if not actual colonies, Latin American nations were nevertheless both economic and political colonies:

All of Latin America must be regarded as a colony of the United States, not just its colonies in the strict sense such as the Philippines, and so on. The United States completely controls Central America with its army of occupation. But it also controls Mexico and South America, where this is expressed in two ways. It does this, first, by economic and financial penetration, which has increased since the German enterprises in these countries were expropriated. Second it applies the Monroe Doctrine, which originally protected America from the monarchical system, but 
has become a tool for the consolidation of U.S. imperialism and its supremacy in Latin America (RIDDELL, 1991, p. 229).

He concluded that given this situation:

It is absolutely necessary to fight this imperialism by launching revolutionary movements in Latin America, just as it is necessary to act against British imperialism by staring revolutionary movement in its colonies (RIDDELL, 1991, p. 229).

The Communist International sent three organizers to Mexico in the early 1920s: Charles Francis Phillips and Louis Fraina of the United States and Sen Katayama of Japan. While they succeeded in recruiting a few worker and peasant leaders, the Communists could not compete with the revolutionary nationalist ideology produced by the Mexican Revolution. While they did help to re-found the Mexican Communist Party on a broader base, it remained a small party with little impact, faced with severe repression. While it would stumble on through the 1920s, it remained a marginal political current (SPENSER, 2011, passim).

The Communist International's ability to control and direct is affiliated parties in Latin America during the first decade - that is, from the founding of the International in 1918 until Stalin took command of the Soviet Union and of the International in 1927 was extremely limited. From October 1917 until 1922, the Russian Communist government was preoccupied with foreign intervention and a civil war. Following the end of the civil war, the leadership was focused on ending the period of "War Communism" and implementing the New Economic Policy (NEP). Then in 1924, Lenin died, opening the period of factional struggle between Stalin, Kamenev, Zinoviev, Bukharin and Tomsky. At the same time, Zinoviev led the $\mathrm{CI}$ in the "Bolshevization" campaign, intended to make over all of the affiliated parties around the world in the image of the Bolshevik party, but also as serving as a campaign against Trotskyism and Luxemburgism. ${ }^{15}$

15 Zinoviev's Bolshevization project was principally an attack on Trotsky, but lumped his ideas together with those of Rosa Luxemburg (GEIER, [s.d.]). 
Until 1923 when the Communist International's attempt to foment a German Revolution failed, attention had been on Europe. But then Russian Communists and the $\mathrm{CI}$ turned their attention from Europe to China. For the Russian Communists Latin America remained distant and - with the exception of revolutionary Mexico - for the moment politically irrelevant. The Russians and other European Communists tended to be ignorant of Latin America's history, its economic structures, its society, culture, and peoples. The CI languages were Russian, German, and French; few Communists knew Spanish, and they had no idea about the indigenous languages of the continent. Latin American capitals remained a week or more away by train and steamship, though messages with instructions could be and were sent by cable. Still, the Communists believed they had a universal plan for world revolution. Moreover, the prestige of the Russian Revolution and the Communist International's role as the leading body of the party of world revolution meant that the CI's theory of revolution and of the revolutionary party were transmitted to the Latin American left and then to its new Communist parties, however incompletely and inexactly.

How was the Communist International received in Latin America? Mexico was unique in that it was in the throes of a long, bloody, and deeply divided revolution and civil war, which was coming to a conclusion just as the CI was established. As mentioned above, Mexico's Communist Party, founded by foreigners living in Mexico, had only a small following at first; and the new party soon found itself in competition with both the declining anarchist movement and, more important, the rising Mexican nationalist state. In Argentina, Chile, and Uruguay, countries with large European immigrant populations and Socialist parties of some significance, the Communist parties emerged between 1918 and 1921 from the Socialist parties, much as had happened in Europe, through a process of splits over the Bolshevik model and the famous "21 conditions" required to join the CI (LENIN, 1920). Only the Chilean Socialist Workers' Party went over in its entirety to the Communist International. In Brazil, where anarchism dominated the labor movement, small groups of intellectuals came together 
to found the Brazilian Communist Party in 1922. The Communist Party of Cuba was organized by a group of students in 1925 . Communist Parties in Guatemala and El Salvador were also established that year. Ecuador and Panama had Communist parties by 1926. Columbia, Paraguay, and Peru had no Communist party until 1928, while Venezuela did not have a Communist Party until the early 1930s and Bolivia until the beginning of the 1940s (POPPINO, 1964 , p. 55 - 95; 224 - 229). The Communist parties that were established in Latin America between 1918 and 1928 experienced a variety of political and organizational crises, some caused by the factional struggles in the Soviet Union, and consequently most had little significant impact on their respective nations. ${ }^{16}$

The CI made anti-imperialism a major focus of its Latin American political work. In 1925, the Communist International played a central role in creating a united front with other groups in Latin America to create the Anti-Imperialist League of the Americas (Liga Antiimperialista de las Americas - LADLA), involving Latin American intellectuals with a variety of views. The LADLA had as its major project the "Hands Off Nicaragua" campaign and support for Augusto César Sandino and his fight against the U.S. Marines. In 1927, the LADLA participated in the International Congress against Colonial Oppression and Imperialism held in Brussels. The Congress Resolution on Latin America called for a struggle against the rival Yankee and British imperialisms in the region. The resolution condemned the role of the AFL in Latin America, called for a united front of Latin American labor unions, and for their involvement in the anti-imperialist movement (RÉSOLUTION..., 1927). This united front approach ended abruptly in 1928, only a year from its initiation.

In 1929, with Joseph Stalin having taken hold of the Soviet and the Communist International, and now advocating the notion of viability of "socialism in one country" things changed dramatically. As former Spanish Communist Party member Fernando Claudín

16 Perhaps the most important and interesting experience was that of Peru, where Carlos Mariátegui founded the Socialist Party of Peru, which affiliated with the CI. See La Botz (2012). 
(1975, p 76 - 77) writes, "from the moment when the building of socialism in the USSR was seen as the essential determining factor of the world revolution, all other movements were reduced objectively to a subordinate role, and it was from that angle that they had to be regarded in the Comintern's strategy and tactics". Exactly when that moment occurred is unclear, but it had certainly taken place by the time that Stalin took power. Only after 1928, when Stalin had taken control of both the Soviet Union and the Communist International, did the $\mathrm{CI}$ and its Latin American parties begin to have a more significant effect, though that was often unfortunate and sometimes disastrous.

\section{THIRD PERIOD}

With Stalin now leading the Communist International, at its Sixth World Congress held in Moscow in 1928, it entered its "Third Period". In Communist terms, the first period, from 1918 to 1923 had been one of revolutionary upheaval; the second period from 1923 to 1928, one of capitalist consolidation; but the Third Period was expected to be one of capitalist crisis and new revolutionary opportunities, and Communists were directed to seize them. The Communist International leadership advanced the theory of "social fascism," insisting that the Social Democratic and Labor parties were not simply reformist, but actually fascist, social fascist. Consequently the Communists could not use the united front strategy of allying with the Socialists as they had in the earlier periods; in fact, the Communists must and would engage in struggles, sometimes violent, against the Socialists. The Communists in this period of "class against class" would also attempt to initiate and to lead revolutionary insurrections. In Latin America they would do so with terrible results.

The Comintern held a Latin American Conference in December 1927, attended by eight representatives of Latin American countries as well as two Comintern representatives. The following year, the Communist International moved its Latin American Bureau or Secretariat from Moscow to Buenos Aires under the leadership of a Lithuanian named Guralsky. There were at the time about 25,000 
Communists altogether in all of the Latin American parties. The new secretariat was given responsibility to strengthen the CPs, to found labor unions and peasant organizations, increase publishing of literature, and to enforce $\mathrm{CI}$ discipline on the parties. One Latin American declared that the Communists had finally "discovered Latin America" (ALBA, 1968, p. 122 - 126). The first Latin American Communist Conference in Buenos Aires followed in 1929, with 28 delegates from fourteen countries. The secretariat led by Guralsky, a Bulgarian named Stoyan Mineevich, known as Stepanov, and Victorio Codovilla, took charge of directing the Latin American parties in the Third Period (ALBA, 1968, p. 125 - 130).

The two most significant Communist Third Period debacles occurred in Colombia and El Salvador. The Communists in Colombia in 1928 intervened in a banana workers strike and attempted to turn it into an insurrection with the goal of sparking revolution. In response the military intervened, eventually leading to the death of over 1,000, with 3,600 wounded, and 500 arrested, most of those going to prison. Refusing to work with liberals and socialists, the Communists led the strike to a catastrophic defeat (ALBA, 1968, p. 127).

More disastrous was the Communist leadership of a peasant rebellion against the military dictatorship that had taken power in El Salvador in December 1931. When the military government refused to recognize the Communist Party's claim that it had won the 1932 election, the party decided to organize an insurrection (GOULD, 2008; ANDERSON, 1971). The government massacred somewhere between 10,000 and 30,000 rebels. Among those executed was Agustín Farabundo Martí, the head of the party. Robert J. Alexander wrote, "The suppression of the revolt of 1932 destroyed the Communist Party, all of its front organizations, and the labor movement as well and installed [Maximiliano Hernández] Martínez as a dictator, a regime which lasted for a dozen years" (ALEXANDER, 1957, p. 366 - 371). The 1932 revolt also contributed to the decline if not the complete disappearance of indigenous identity in El Salvador (CHING; TILLEY, 1998). The Salvadoran CP was not reorganized until 1936. 
The Third Period's impact everywhere, including in Latin America, was firstly to strengthen the grip of the Comintern on Communist parties, purging them of all dissident elements; ${ }^{17}$ secondly, to give Communist leadership to adventurous, ultra-left actions that led to devastating results; and thirdly, through that process, to create a hardened cadre of absolutely loyal Communists and courageous fighters, veterans of struggles against the capitalist and landlord classes, against reformist socialist parties and labor unions. The Third Period created Communist parties made up of men and women who were prepared to follow Stalin's International whatever course it took. None of this contributed to the building of that independent socialist workers movement which stood at the heart of Marxism. As Nicola Miller writes, "The Communist International failed to turn any political situation to its advantage during the years 1917-1935, largely because of the rigidity of its model and its lack of interest in the actual conditions of Latin America." (MILLER, 1989, p. 41).

\section{POPULAR FRONT}

With Adolf Hitler's ascension to power in Germany in 1933, Stalin and the Soviet leadership began to rethink Communist policy. Hitler soon destroyed the German Communist Party, the largest outside of Russia, and his Reich represented an imminent threat to the Soviet Union and the ruling Communist bureaucracy. Stalin abandoned the sectarian and ultra-left Third Period and in mid-1936 adopted the Popular Front. The Popular Front called upon the Communists to ally everywhere with all anti-fascist forces, which generally meant not only with the labor and socialist parties, but also with bourgeois parties, and even in some places with thoroughly reactionary governments and parties so long as they opposed fascist Italy and Nazi Germany. While Communist leaders and cadres still hoped to bring about revolutions that would create governments like that of the Soviet Union, their participation in

17 The dissidents often went off to found their own leftwing parties, Trotskyist, Socialist, or dissident Communist. 
labor coalitions with socialist and nationalist unionists and their adoption of a regular electoral political approach, together with rhetoric in praise of bourgeois democracy, made the Communists more acceptable and even popular in various countries.

The Popular Front was undergirded by a theory of revolution similar to that of the Social Democratic parties of the late nineteen and early twentieth centuries. It was a theory of economic development through stages. Latin America, it was argued, was a region where feudal social structures still existed; where a landed aristocracy held as vassals the vast impoverished peasantry. Consequently, the central struggle was for bourgeois democracy. Latin American revolutionaries should therefore organize workers and peasants and seek an alliance with the "progressive national bourgeoisie." Once a capitalist economy and a liberal state had been established, it would be possible for the working class to undertake the struggle for socialism under the leadership of the Communist Party. The theory was complicated, however, by the fact that the capitalist governments were now divided between the liberal democracies and the fascists, so Communists had to support the democracies (England, France, and the United States) through the construction of the Popular Front, though in some cases they might even support reactionaries or dictators who formed part of the anti-fascist alliance. Leftist groups that attempted to fight for socialism might disrupt the anti-fascist movement and derail the struggle for bourgeois democracy.

Chile became the showcase for the Latin American Popular Front. There the Communists, who had opposed the short-lived Socialist Republic of 1932 led by Marmaduke Grove, now sought an alliance with the Socialists and Trotskyists (ALEXANDER, 1973, p. 194 - 197; MUÑOZ CARRILLO, 2014). Socialist and Communist labor unionists united in the Confederación de Trabjadores de Chile $(\mathrm{CTCH})$. Then the Socialists and Communists, together with the bourgeois Democratic Party joined together to form the Popular Front. The Front's candidate, Pedro Aguirre Cerda of the bourgeois Radical Party, won the presidential race, but the Communists refused to accept any ministerial portfolios. In no other Latin American country did the Communist Party succeed in creating a Popular 
Front, though in Mexico they backed the government of Lázaro Cárdenas, considering that to be that country's unique version of the Popular Front. In other countries they backed capitalist parties and even dictatorships that supported the anti-fascist Allies.

With the negotiation of the Hitler-Stalin Pact, the Communists immediately found themselves isolated. The Communists refused to support the Allied nations in their struggle against Nazi Germany. Arguing that England and France were the imperialist aggressors, the Communists called for peace. The Communists' position aligned them objectively with rightwing elite groups throughout Latin America that supported the Nazis against Great Britain, the dominant imperial power in the region at the time. The Hitler-Stalin Pact was, however, short-lived and with the invasion of the Soviet Union in June of 1941, the Communists returned to the Popular Front and became the most ardent supports of the Allies against the Axis Powers. Everywhere the Communists became nationalists, patriots, and anti-fascists, quickly becoming acceptable and even popular once more. Again Chile became the showcase of the Popular Front, with the Communists becoming leaders of the $\mathrm{CTCH}$ and with three Communists becoming ministers in the government. Once part of the Chilean government, the Communists worked against non-Communist unions and even assassinated socialists and anarcho-syndicalists in the streets (ALBA, 1968, p. 139). In Mexico, the Communist Party continued to support Cárdenas and the nationalist government party, while party members participated in attempts on the life of Leon Trotsky, who was eventually killed by a Spanish Communist (GALL, 1991).

With the Soviet Union allied with the "democracies" of the Allied Powers, that is, with the British, French, and U.S. empires, Stalin's chief goal became winning and maintaining the good will of those governments. Earl Browder, head of the Communist Party USA and also the leader of the Latin American Secretariat of the Comintern, enthusiastically accepted and implemented these policies. Then, as Claudín writes, "the Comintern was dissolved quite suddenly, in the spring of 1943, on Stalin's orders, so as to facilitate negotiations with Roosevelt and Churchill, whose aim was not merely to secure Germany's defeat, but also to ensure the 
partition of the world among the 'Big Three'." (CLAUDíN, 1975, p. 18). During the war "[...] renouncing any intention of 'fomenting worldwide revolution' was the necessary condition for a far-reaching agreement, based on a share-out of 'spheres of influence,' with American imperialism. And this was one of the essential aims of Stalin's policy" writes Claudín (1975, p. 24).

The Communists became part of the "Grant Alliance" under the hegemony of the United States (CLAUDÍN, 1975, p. 622). In Cuba, the Communists joined in an alliance with the U.S.-backed strongman Colonel Fulgencia Batista, a partnership that lasted from 1938 to 1944. (CABALLERO, 1986, p. 120 - 129) In Nicaragua the Communists attempted to ingratiate themselves with the dictator Anastasio Somoza García (LA BOTZ, 2016, p. 112 - 113). The Latin American Communist parties supported other dictators as well, so long as they were part of the international anti-fascist political and military alliance. Nevertheless, despite the Communists' support for dictators in some Latin American countries, the party grew in size, influence, and popularity in many. According to Claudín, "The Latin American parties combined had 90,000 members in 1939. Around 1947 they had nearly half a million" (CLAUDÍN, 1975, p. 309).

\section{POST-WAR, COLD WAR COMMUNISM: CRISIS AND FRAGMENTATION}

With the Allies' victory over Germany in Europe and over Japan in the Pacific theater, the war ended and almost immediately the Cold War began. Winston Churchill's "iron curtain" speech on March 4, 1946 - "From Stettin in the Baltic to Trieste in the Adriatic, an iron curtain has descended across the continent" - can be taken as the inflection point (HINTON, 1946). The U.S. government brought together 21 American nations in 1948 to create the Organization of American States (OAS), which would become the principle political vehicle for imposing U.S. policy on Latin America governments. The center of that policy was anti-Communism. The U.S. State Department and the new U.S. Central Intelligence Agency (CIA), working closely with the AFL-CIO began a campaign to reduce the power of the Communist Parties and labor federations in Latin 
America. Many Latin American governments cooperated with the United States in the suppression of Communist activity, some of them like Mexico, quite enthusiastically. The Communists-even though they continued to advocate Popular Front politics-were put on the defensive throughout the Western Hemisphere from the late 1940s through the 1950s. In Guatemala where presidents Juan José Arévalo and Jacobo Árbenz led administrations that championed agrarian reform, threatening the interests of a major U.S. corporation, the United Fruit Company, the Communist Party's support for the government was used to justify a CIA inspired military coup in 1954. The CIA specifically targeted Communists for assassination (DOYLE; KORNBLUH, 1997).

While the Comintern had dissolved in 1943, the Soviet Union continued through the Cominform (1947 - 1956) and later through the Soviet government and its embassies to set the line for the world's Communist Parties, including those in Latin America. Top Communist Party leaders and intellectuals such as Caio Pardo Júnior in Brazil, found it very difficult to break with the Soviet Union, despite their differences (PERICÁS, 2016, p. 280).

Soviet Communism went into crisis in February 1956 with Russian Premier Nikita Khrushchev's secret speech at the Twentieth Party Congress of the Communist Party, in which he denounced Stalin's dictatorship, his cult of personality, and his crimes against Communist Party members and Soviet citizens. The speech soon fell into the hands of Israel and was passed onto the United States, which made the contents public (U.S. STATE DEPARTMENT, 1956). The speech caused a profound crisis both within the Soviet Communist Party and the international Communist movement. Then, in October of 1956 the Hungarian people revolted against Soviet domination and Communist rule, a workers' revolution against Communism that the Soviet Union put down with tanks. Soviet relations with the West remained based on the concept of "peaceful coexistence" and the conviction, as Khrushchev put it, "History is on our side; we will bury you" (WHITMAN, 1971). That is, that Soviet Communism and the global Communist movement would, in the long run, overcome capitalism. The Communist 
parties in Latin America operating within that framework and within the Popular Front model - that is, pursuing social change through parliamentary elections, progressive coalitions, and labor union struggles to improve workers' lives - engaged in no revolutionary or insurrectional movements. It was precisely this opposition to revolution in the Western Hemisphere that led the Communists to turn away the young Cuban lawyer Fidel Castro.

The Cuban Revolution of 1959, led by Castro's "26 of July" guerrillas in la sierra madre with support from student and labor groups in el llano, provided a new model of revolution for Latin America. The Cuban revolution had nothing to do with either Karl Marx's theory of the revolutionary potential of the working class or with Lenin's claim that the working class needed a Bolshevikstyle party. Nor did it follow any of Joseph Stalin's various Third Period or Popular Front strategies; and it had even less to do with Khrushchev's peaceful coexistence. Castro and his band of déclassé revolutionaries, acting in small guerrilla bands and espousing a program of democracy and social reform, overthrew the Batista dictatorship. While the United States recognized Cuba almost immediately after the revolution, President Dwight D. Eisenhower and the CIA soon began to plot Castro's overthrow and established an embargo of Cuba. When John F. Kennedy became president in 1961 he used the CIA to organize the abortive Bay of Pigs invasion in an attempt to overthrow Castro. Meanwhile Castro simultaneously declared Cuba socialist, and then brought Cuba into the Soviet camp, while in 1965 he merged his guerrilla organization with the Cuban Communist Party (FARBER, 2006).

Castro's compañero Ernesto "Che" Guevara argued that the Cuban experience should be seen as a revolutionary model for Latin America. He believed that guerrilla groups organized in focos-that is, small bands in a particular area-would be able to sweep down from the mountains to lead revolutions throughout the continent, just as they had in Cuba (GUEVARA, 1978; FARBER, 2016). The French intellectual Régis Debray turned this notion into a theory in his book Révolution dans la Révolution (DEBRAY, 1967). As Roberto Regalado writes: 
A new generation of young leftists, of diverse ideological identities and political affiliations - social Christians, Social Democrats, Socialists, Communists, Trotskyists, Guevarists, and others - coming from the student, worker or peasant movement, embraced the form of struggle that had been practiced successfully by Fidel and Che (REGALADO, 2013, p. 76).

Inspired by the Cuban Revolution, following the prescriptions of Guevara and Debray, and often with Cuban support, young people organized guerrilla groups throughout Latin America with disastrous consequences almost everywhere. Guevara himself was killed in a failed attempt at a guerrilla revolution in Bolivia in 1967. Debray decided that it had all been a mistake (DEBRAY, 1974; CASTAÑEDA, 1993). Only in Nicaragua was such a revolution successful and that was two decades later (LA BOTZ, 2016). The period that began with the Cuban Revolution and left wing guerrilla insurrections became between 1964 and 1985 an era of rightwing dictatorships in all of the Southern Cone of South America and much of Central America. The rightwing national security states kidnapped, tortured, and murdered thousands of leftists and outlawed their parties, virtually annihilating the Left for a generation.

A few years later, in the early 1960s, Mao Tse-tung, leader of the Chinese Communist Party, launched an attack on Khrushchev and the Communist Party of the Soviet Union, arguing that they had become "revisionist." While Stalin, Mao argued, had defended the dictatorship of the proletariat, Khrushchev and his "clique" had become pro-capitalist (TSE-TUNG, 1964). The split between the Soviet Union and Communist China was the most important development in world communism in the latter half of the twentieth century. A couple of years later, in 1966, Mao launched the Great Proletarian Cultural Revolution, supposedly a proletarian struggle against capitalist elements within China, a development that made China immensely popular among young radicals around the world and in Latin America (ROTHWELL, 2012). The Maoists remained popular and influential even after Mao welcomed Richard Nixon to China in 1972 and began a tacit alliance with the United States. Maoists in Latin America organized in 
labor unions, peasant leagues, and among the urban poor. Like the Stalinist Communism that had given birth to it, Latin American Maoism alternated between Popular Front politics and Third Period voluntarism. In Peru Abimael Guzmán's Sendero Luminoso, founded in the 1960s, launched a violent campaign in 1980 - including attacks on other socialist groups - that over several years took the lives of 60,000 people (ROTHWELL, [s.d.]). In the 1990s the rightwing authoritarian Peruvian president Alberto Fujimori suppressed Sendero Luminoso with the military and through thousands of civilian self-defense committees.

In addition to the appearance in Latin America of Cuban and Chinese Communism, Trotskyist groups, which had existed in Latin America since the 1930s, also grew in significance in the 1970s. The Trotskyists Partido Obrero Revolucionario (POR), had played a key role in the Bolivian Revolution of 1952, though losing out in the end to the bourgeois Movimiento Nacional Revolucionario (MNR). Other Trotskyist groups existed in various Latin American nations, though their influence tended to be limited. ${ }^{18}$ During the 1960s and 1970s, the Trotskyist Fourth International led by Ernest Mandel became more significant in Europe, especially in France, and also took an interest in Latin America. The Fourth International supported the Cuban Revolution and also tended to be sympathetic to Che Guevara and the armed struggle groups, while some Latin American Trotskyists plunged headlong into the armed movements. As Daniel Bensaïd wrote of his youth in France, "Latin America was a kind of twin continent in our political imagination. Cuba had proclaimed itself the first liberated territory of the New World. Che had abandoned the exercise of power to devote himself to permanent revolution" (BENSAÏD, 2013, p. 75). But when he went to Argentina in 1973 he wrote, "Our comrades were young and intrepid, full of confidence in the socialist future of humanity. Three years later, half of the people I met at these meetings had been arrested, tortured and murdered. It was clear we were on the wrong path" (BENSAÏD, 2013, p. 132).

18 Alexander (1973). To get some sense of the complexities of international Trotskyism see De Pablo (2005). 
Though challenged by Guevarism, Maoism, and Trotskyism, pro-Soviet Communist parties continued to play a significant role in several Latino American countries. Most important was the Chilean Communist Party's proactive role in the election in 1970 of Salvador Allende to the presidency of Chile as the candidate of Unidad Popular, a popular front coalition of the Communist, Socialist, and Radical parties. Allende, who received a plurality of 36 percent of the vote, moved swiftly to nationalize mines and factories and to carry out an agrarian reform. Finally, the Communist Party's Popular Front politics appeared to be vindicated. Allende reestablished diplomatic relations with Cuba, and Fidel Castro visited Chile in 1971, spending nearly a month touring the country. Chile's conservative elite and the military, with the support of the CIA, overthrew the Allende government on September 11, 1973. General Augusto Pinochet's military government killed thousands, many of them Communists, and drove thousands of others into exile. Allende's fall, which had initially seemed to vindicate the Communists' Popular Front strategy, now appeared to condemn it. The far left drew the conclusion that if you do not overthrow the capitalist state, it will overthrow a leftist government (PRIETO, 2014 [1974]). On the other hand, Communist China, which had welcomed Richard Nixon in 1972, quickly recognized the Pinochet dictatorship shortly after the 1973 coup (ROTHWELL 2012, p. 25). With Deng Xiao Ping's rise to power in China and his adoption of pro-capitalist policies, many pro-China Communist parties abandoned support for China, but remained Maoists (LA BOTZ, 2012).

As Valter Pomar of the Brazilian Workers Party (PT) writes:

The Latin American Left was defeated everywhere in the 1960s and the beginning of the 1970s: the Cuban Revolution was blockaded; other popular nationalist and revolutionary processes were defeated; Latin American guerrillas had no success; the Popular Unity experience [in Chile] ended in a tragic way; a great part of the continent was subjected to de facto or de jure dictators (REGALADO, 2013, p. 65).

The meeting of all Latin American Communist parties in Havana, Cuba in 1975 represented their response to the defeat 
of Guevara's foquismo as well as to Pinochet's overthrow of the Popular Unity government in Chile. The Communist Parties would reject the foco, and return to the building of mass organizations and to Popular Front gradualism. (MILLER, 1989, p. 54) The heyday of guerrilla revolution was over.

The world Communist movement took another turn in the 1970s with the rise of Eurocommunism, which also affected Latin America. While the Popular Front had resembled Social Democracy, it was only a tactic and did not fundamentally affect the Stalinist core of the Communist parties around the world, which still hoped to create a Soviet one-party state. In 1977 the Spanish Communist leader Santiago Carrillo (PRESTON, 2014) published his book Eurocomuniso y Estado, which argued for the transformation of Communist Parties into genuine social democratic parties prepared to govern capitalist states (CARRILLO, 1977). Historian Barry Carr (1985) has argued that the Mexican Communist Party took steps in that direction in the late 1970s, and others have suggested that the policy also had an impact on Chile and the future policy of the post-dictatorship Concertación regimes (READ; WYNDHAM, 2015). While Eurocommunism had some impact, the Nicaraguan Revolution of 1979 revived the Guevarist currents, so that both electoralist and guerrilla perspectives continued to compete across the continent.

The Nicaraguan Revolution of 1979 represented the last significant leftward political movement of the radical era of the 1960s and 70s. While the Sandinista Front for National Liberation (FSLN) had adopted the Cuban model and identified with the Soviet camp, it presented itself as committed to social democracy, a mixed, economy, and nonalignment. While the Soviet Union and Cuba supported the Sandinista government, so too did European social democratic governments. U.S. President Ronald Reagan's government actively backed both the civilian opposition and the Contras' armed opposition to the Sandinistas. After a decade of civil war, the Nicaraguan people, exhausted by the revolution and civil war, voted the Sandinista government out of office in 1990 (LA BOTZ, 2016). 


\section{THE WASHINGTON CONSENSUS AND THE FALL OF COMMUNISM}

The end of the twenty-year era of military dictatorships in Latin America began in the mid-1980s and the return to parliamentary democracy coincided with the rise of the Washington Consensus and neoliberalism. Throughout Latin America in countries previously ruled by dictatorships, new party systems, usually dominated by a conservative and a social democratic party were established and conservatives took power at first, sometimes followed by social democrats, though both sorts, working with the International Monetary Fund and the World Bank generally accepted structural adjustments and imposed neoliberal economic policies. Then in 1991, Soviet Communism collapsed.

The Soviet Union's control over Eastern Europe had been challenged on numerous occasions by popular upheavals: the East German rebellion of 1953, the Hungarian Revolution of 1956, the Prague Spring of 1968, and most importantly the Polish Solidaność national strike in 1980 (HARMAN, 1974; SINGER, 1981). While there were many minor rebellions within the Soviet Union itself, none succeeded in challenging, much less overturning, the Communist government. A series of internal economic and political crises finally led to the dissolution of the Soviet Union and the end of the Communist government in 1991. The fall of Soviet Communism meant the end of its tutelage over dozens of Communist Parties around the world (REGALADO, 2013; 2012).

The collapse of Communism in the Soviet Union was ideologically and politically devastating to much of the old Left everywhere. Official Communist Parties which had seen the Soviet Union as a model were demoralized and disoriented by what was for them a catastrophic event. Some Socialists and Trotskyists who had also supported the Soviet Union, however critically, were also devastated by the fall of Communism. In the wake of the fall, the former Communist Parties followed various trajectories, many adopting a social democratic programs and strategies.

By the twenty-first century, Soviet Communism's influence in Latin America existed mostly as a memory. New labor and social movements arose and won elections in several Latin American 
nations - most prominently Argentina, Brazil, and Venezuela - in what was called the "pink tide." As two leading Latin Americanists wrote at the time, "[...] many of the political party formations that currently make up the pink tide have little if any imbrication in the history of the left wing as it has developed over the past century" (WEBBER; CARR, 2013, p. 4). Propelled by popular movements of the indigenous, the urban poor, women, and new labor (LA BOTZ, 2007) organizations, the new progressive governments, buoyed by the expanding Chinese economy and the boom in commodity prices, established what have been called compensatory states (needs source). Some saw the World Social Forum hosted by the Workers' Party in Puerto Alegre in 2001 as the initiation of something like a new socialist international. But the global economic crisis of 2008 and the fall in commodity prices a few years later destroyed the economic underpinnings of the left governments none of which could be called socialist - and rightwing parties have driven them from power in Argentina and Brazil (WEBBER, 2017).

\section{BY WAY OF A CONCLUSION}

Towards the end of his history of the Communist International, Pierre Frank, the French Trotskyist who served in the leadership of the Fourth International, asks, "What is the balance sheet of the Communist International?" Many, he says would say that it is negative. But, he suggests, that is too simplistic. He comes to the conclusion that it is a "precious acquisition for the future of the workers' movement" (FRANK, 1979, p. 887). It was, he argues in the final chapter, a useful attempt at creating what Rosa Luxemburg thought a socialist international should be: "a center of gravity" (FRANK, 1979, p. 889 - 912). Frank was writing almost exclusively about the Communist International's role in Europe and Asia, where the organization's impact was greater and the stakes higher. Whether or not he is right about that region is a question that has been debated at length by many historians. In Latin America, however, the Communist International's impact was certainly completely negative. 
The Communist International occupied the space that a genuine international might have occupied as the Communist Parties competed for the political space that might have allowed for the rise and flourishing of genuine revolutionary socialist parties. The Communist Internationals' authoritarian and hierarchical subordination of all Communist Parties to the foreign policy of the Soviet Union disastrously distorted the Latin American Communist Left. A real revolutionary socialist movement could only develop through democratic processes, which were completely alien to the Communist tradition, certainly after 1924.

The experience of the Russian Revolution, a genuine revolution from below; and the early years of the Communist Party, a truly revolutionary party until the mid-1920s; remain an inspiration to small groups of revolutionaries in Latin America, mostly out of the Trotskyist tradition. Other revolutionaries have also developed out of their own experiences the understanding that international socialism must be constructed on the basis of a revolution from below, democratic practices, and a genuine internationalism. Whether or not these small groups will be able to prove more successful than the Communist International remains to be seen, but at the moment the entire Latin American left is on the defensive.

\section{REFERENCES}

AGUIRRE, C. Militantes, intelectuales y revolucionarios: ensayos sobre marxismo e izquierda en América Latina. Raleigh, NC: Editorial Contracorriente, 2013.

ALBA, V. Politics and the Labor Movement in Latin America. Stanford, CA: Stanford University Press, 1968.

ALEXANDER, R. J. Communism in Latin America. New Brunswick, N.J.: Rutgers University Press, 1957.

Trotskyism in Latin America. Stanford, CA: Hoover Institution Press, 1973.

ANDERSON, K. Marx at the Margins. Chicago: University of Chicago Press 2016.

ANDERSON, T. Matanza. Lincoln: University of Nebraska Press, 1971. 
ARENDT, H. The Origins of Totalitarianism. New York: Harcourt, Brace \& Company, 1976 [1951].

BARRETT, J. R. William Z. Foster and the Tragedy of American Radicalism. Urbana: University of Illinois Press, 1999.

FOSTER, W. Z. History of the Three Internationals. New York: International Publishers, 1955.

Outline Political History of the Americas. New York: International Publishers, 1951.

BENSAÏD, D. An Impatient Life: A Memoir. New York: Verso, 2013.

BIOGRAPHICAL Sketch. Guide to the Robert J. Alexander papers at Rutgers University, [s.l.: s.d.]. Available at: <http://www2.scc.rutgers. edu/ead/manuscripts/alexanderf.html>. Access on: Oct. 02, 2017.

CABALLERO, M. Latin America and the Comintern, 19191943. New York: Cambridge University Press, 1986.

CARR, B. Mexican Communism 1968-1981: Eurocommunism in the Americas?, Journal of Latin American Studies, Cambridge, v. 17, n. 1, p. 201-228, 1985.

CARRILLO, S. Eurocomunismo y Estado. España: Crítica, 1977.

CASTAÑEDA, J. Utopia Unarmed: Latin America after the Cold War. New York: Knopf, 1993.

CHIBBER, V. Post-Colonial Theory and the Specter of Capitalism. London: Verso, 2013.

CHING, E.; TILLEY, V. Indians, the Military and the Rebellion of 1932 in El Salvador. Journal of Latin American Studies, Cambridge, v. 30, n. 1, p. $121-156,1998$.

CLAUDÍN, F. The Communist Movement: From Comintern to Cominform. New York: Monthly Review Press, 1975. 2 v.

DE PABLO, Ó. A la izquierda del margen: los trotskismo internacionales en México, 1958 - 2000. [S.l.: S.n.], 2005. [Electronic copy].

DEBRAY, R. La critique des armes. Paris: Éditions du Seuil, 1974. 2 V.

Révolution dans la révolution?: lutte armée et lutte politique en Amérique latine. Paris: F. Maspero, 1967.

DOYLE, K.; KORNBLUH, P. CIA and Assassinations: The Guatemala 1954 Documents. National Security Archives, [online], 1997. Available at: <http://nsarchive.gwu.edu/NSAEBB/NSAEBB4/>. Access on: Oct. 02, 2017. 
FARBER, S. Revolution and reaction in Cuba, 1933 - 1960: a political sociology from Machado to Castro. Alameda: Center for Socialist History, 2007.

The Origins of the Cuban Revolution Reconsidered. Chapel Hill: University of North Carolina Press, 2006.

The Politics of Che Guevara. Chicago: Haymarket Books, 2016.

FRANK, P. Historie de l'International communiste. Paris: Édition la Brèche, 1979.

GALL, O. Trotsky en México: Y la vida política en el periodo de Cárdenas, 1937 - 1940. Mexico: Ediciones Era, 1991.

GEIER, J. Zinovievism and the degeneration of world Communism. International Socialist Review, Chicago, IL, n. 93, s.p., [s.d.]. Available at: <http://isreview.org/issue/93/zinovievism-and-degeneration-worldcommunism>. Access on: Oct. 02, 2017.

GÓMEZ, M. From Mexico to Moscow. Survey: A Journal of Soviet and East European Studies, London, n. 53, p. 37 - 39; 55, 1964.

GOULD, J. L.; LAURIA-SANTIAGO, A. A. To Rise in Darkness: Revolution, Repression, and Memory in El Salvador, 1920-1932. Durham: Duke University Press, 2008.

GUEVARA, E. C. La guerra de guerrillas. La Habana : Editorial de Ciencias Sociales, 1978.

HAITHCOX, J. P. Communism and Nationalism in India: M.N. Roy and Comintern Policy, 1920-1939. Princeton: Princeton University Press, 2015.

HARMAN, C. Bureaucracy and Revolution in Eastern Europe. London: Pluto Press, 1974.

HINTON, H. B. Churchill Assails Soviet Policy. New York Times, [online], Mar. 5, 1946. Available at: <http://www.nytimes.com/learning/general/ onthisday/big/0305.html\#article>. Access on: Oct. 02, 2017.

ISSERMAN, M. Which Side Were You On?: The American Communist Party During the Second World War. Middleton: Connecticut: Wesleyan University Press, 1982.

JACOBSON, J. When the Soviet Union Entered World Politics. Berkeley: University of California Press, 1994.

KERSFELD, D. From Esotericism to Marketing: Approaches to the Comintern Archives. Flacso Ecuador, [online], 2011. Available at: <http://www. flacso.org.ec/docs/i41kersffeld.pdf >. Access on: Oct. 02, 2017.

KINZER, S. Overthrow: America's Century of Regime Change from Hawaii to Iraq. New York: Henry Holt and Company, 2006. 
KLEHR, H.; HAYNES, J. E.; FIRSOV, F. I. The Secret World of American Communism. New Haven: Yale, 1995.

LA BOTZ, D. China: From Bureaucratic Communism to Bureaucratic Capitalism. New Politics, Brooklyn, N.Y., [online], Nov. 20, 2012. Available at: <http://newpol.org/content/china-bureaucraticcommunism-bureaucratic-capitalism>. Access on: Oct. 02, 2017.Top of Form Latin American Marxist: José Carlos Mariátegui. New Politics, Brooklyn, N.Y., v. XIV, n. 1, [s.p.], 2012. Available at: <http://newpol.org/ content/latin-american-marxist-jos\%C3\%A9-carlos-mari\%C3\%A 1 tegui>. Access on: Oct. 02, 2017.

The Role of Labor in Latin America's Left Turn. NACLA, [online], 2007. Available at: <http://nacla.org/news/role-labor-latinamerica\%E2\%80\%99s-\%E2\%80\%98left-turn\%E2\%80\%99 >. Access on: Oct. 02, 2017.

Vicissitudes of a Theory. New Politics, Brooklyn, N.Y., v. XIII, n. 3, [s.p.], 2011. Available at: <http://newpol.org/content/vicissitudestheory>. Access on: Oct. 02, 2017.

What Went Wrong?: The Nicaraguan Revolution: A Marxist Analysis. Netherlands: Brill 2016.

Bottom of FormWrestling with Trotsky, Che, and Political Impatience. New Politics, Brookyn, N.Y., [s.p.], 2014. Available at: <http://www. revistasbolivianas.org.bo/pdf/fdc/v4n9/a03_v4n9.pdf >. Access on: Oct. 02, 2017.

\section{LENIN, V. I., Terms of Admission into Communist International.} [S.l.: s.n.], 1920. Available at: <https://www.marxists.org/archive/lenin/ works/1920/jul/x01.htm>. Access on: Oct. 02, 2017.

LISS, S. B. Marxist Thought in Latin America. Berkeley: University of California, 1984.

LÖWY, M. El marxismo en América Latina (de 1909 a nuestros días): Antología. Mexico: Ediciones ERA, 1982.

The Politics of Combined and Uneven Development: The Theory of Permanent Revolution. London: Verso, 1981.

MARIÁTEGUI, J. C. Textos básicos: selección, prólogo y notas introductorias de Aníbal Quijano. Mexico: Fondo de la Cultura Económica, 1991.

MILLER, N. Soviet Relations with Latin America, 1959-1987. Cambridge: Cambridge University Press, 1989.

MULLAN, M. Víctor Alba (obituary). The Guardian, [online], Mar. 23, 2003. Available at: <https://www.theguardian.com/news/2003/mar/24/ guardianobituaries.booksobituaries>. Access on: Oct. 02, 2017. 
MUÑOZ CARRILlO, G. Disputa por el comunismo en Chile: estalinistas y oposicionistas en el partido de Recabarren (1924-1934). [S.l.: s.n.], 2014. Available at: <http://repositorio.uchile.cl/bitstream/ handle/2250/116098/Mu\%C3\%B1 oz\%20Gabriel_2014.pdf?sequence=1 >. Access on: Oct. 02, 2017.

PERICÁS, L. B. Caio Prado Júnior, uma biografia política. São Paulo: FAPESP, 2016.

PEIRATS, J. La CNT en la revolución española. France: Cary-Colombes, $1971.3 \mathrm{~V}$.

POPPINO, R. International Communism in Latin America: A History of the Movement 1917-1963. London: The Free Press of Glencoe, 1964.

PRESTON, P. Santiago Carrillo: The Last Stalinist. London: William Collins, 2014.

PRIETO, H. Las gorilas están entre nosotros. Santiago: Editorial Viejo Topo, 2014 [1974].

RABE, S. J. The Most Dangerous Area in the World: John F. Kennedy Confronts Communist Revolution in Latin America. Chapel Hill: University of North Carolina Press; 1999.

RADOSH, R. American Labor and United States Foreign Policy. New York: Random House, 1969.

READ, P.; WYNDHAM, M. Eurocommunism and the Concertación: Reflections on Chilean European Exile 1973-1989. Journal of Iberian and Latin American Research, London, v. 21, n. 1, p. 116 - 125, 2015.

REGALADO, R. El derrumbe de la URSS tuvo una repercusión enorme en América Latinal. CubaDebate, [online], Jul. 21, 2012. Available at: <http:// www.cubadebate.cu/noticias/2012/07/21/el-derrumbe-de-la-urss-tuvouna-repercusion-enorme-en-america-latina/\#.WWfDaxPytQI>. Access on: Oct. 02, 2017.

(ed.). La izquierda latinoamericana a 20 años del derrumbe de la Unión Soviética. Coyoacán, Mexico: Ocean Sur, 2013.

RÉSOLUTION sur l'Amérique Latine. League Against Imperialism Archives, [online], 1927. Available at: <https://search.socialhistory.org/ Record/ARCH00804/ArchiveContentList\#Ac280c740f2>. Access on: Oct. 02, 2017.

RIDDELL, J. (ed). The Communist International in Lenin's Time: Workers of the World and Oppressed Peoples, Unite! Proceedings and Documents of the Second Congress, 1920. v. I. New York: Pathfinder, 1991. 
ROLLIE E. Poppino (Obituary). U.C. Davis, [online], Feb. 1, 2011. Available at: <http://www.davisenterprise.com/Archived-Stories-0/rollie-epoppino/>. Access on: Oct. 02, 2017.

ROTHWELL, M. D. Transpacific Revolutionaries: The Chinese Revolution in Latin America. London: Routledge, 2012.

Influencia de la Revolución China en America Latina: México, Perú, y Bolivia. Revistas Bolivianas, [s.l.], v. 4, n. 9, p. 5 -11, [s.d.]. Available at: <http://www.revistasbolivianas.org.bo/pdf/fdc/v4n9/a03_v4n9.pdf>. Access on: Oct. 02, 2017.

SHIPMAN, C. It Had to be a Revolution: Memoirs of an American Radical. New York: Cornell University Press, 1993.

SINGER, D. The Road to Gdansk: Poland and the USSR. New York: Monthly Review Press, 1981.

SPENSER, D. The Impossible Triangle: Mexico, Soviet Russia, and the United States in the 1920s. Durham: Duke University Press, 1999.

TROTSKY, L. The Revolution Betrayed: What is the Soviet Union And Where Is It Going?. London: New Park Publications, 1967.

TSE-TUNG, M. On Khrushchov's Phoney Communism and Its Historical Lessons for the World: Comment on the Open Letter of the Central Committee of the CPSU (IX). [S.1.: S.n.], 1964. Available at: <https:// www.marxists.org/reference/archive/mao/works/1964/phnycom.htm>. Access on: Oct. 02, 2017.

U.S. State Department. Office of the Historian. Khrushchev and the Twentieth Congress of the Communist Party, [online], 1956. Available at: <https://history.state.gov/milestones/1953-1960/khrushchev-20thcongress >. Access on: Oct. 02, 2017.

WEBBER, J. R. The Last Day of Oppression, and the First Day of the Same: The Politics and Economics of the New Latin American Left. Chicago: Haymarket Books, 2017.

WEBBER, J. R.; CARR, B. The New Latin American Left: Cracks in the Empire. New York: Roman \& Littlefield Publishers, Inc., 2013.

WHITMAN, A. Khrushchev's Human Dimensions Brought Him to Power and to His Downfall. The New York Times, [online], Sept. 12, 1971. Available at: <http://www.nytimes.com/learning/general/onthisday/bday/0417. html>. Access on: Oct. 02, 2017.

WILLIAMS, W. A. Empire as a way of Life. New York: Oxford University Press, 1980. 